\title{
Liturgical Inculturation: Decolonization or Decolonialization? Examining Misa ng Bayang Pilipino
}

\author{
Edward FOLEY \\ Catholic Theological Union, Chicago, Illinois
}

\begin{abstract}
Roman Catholic eucharistic worship is steeped in Western traditions and law. Since Vatican II there has been permission for the inculturation of worship, including the Eucharist. This study will explore to what extent such inculturation is true decolonization while continuing to be a faux decolonialization. The thesis being tested here is that inculturation as a form of liturgical decolonization returns the "sacred land" or liturgical terrain-for example, language, architecture, vesture, music, and so forth-to various indigenous peoples, societies, and even countries. Such decolonizing, however, is not necessarily a decolonializing. The epistemic frameworks and European (even medieval) imagination foundational for the legal and theological frameworks that officially define Roman Catholic Eucharist are seldom if ever challenged, much less changed. The underlying question is whether Roman Catholic Eucharist can ever achieve true decolonialization.
\end{abstract}

\section{Keywords}

inculturation, coloniality, colonization, liturgy, Misa ng Bayang Pilipino

\section{INTRODUCTION}

One of the privileges of teaching at Catholic Theological Union is our array of international students, many of whom are from the Philippines. One of them introduced me to Misa ng Bayang Pilipino (hereafter MBP), thereby providing the case study for this essay. That liturgical adaptation was largely the work of Anscar Chupungco (d. 2013), colleague, collaborator, and friend. He encouraged my study of $M B P$. 
As a U.S.-born Caucasian, I profess not to know much about the Philippines. This study could be considered a colonial act: my intruding into an indigenous ritual arena. Filipino colleagues and students, however, have encouraged this work and aided me immensely. My hope is that this exercise in practical theology honors the many ways they have taught me.

The basic question behind this work is to what extent official Roman Catholic worship can be decolonized and decolonialized.

\section{DeFINITIONS}

Moments and movements are difficult to define. Decoloniality, alternately considered moment and movement, is no exception. ${ }^{1}$ One step is distinguishing coloniality from colonialism. Walter Mignolo distinguishes decolonial thinking from postcolonial theory genealogically: the latter located in French post-structuralism, the former in "the dense history of planetary decolonial thinking." ${ }^{2}$ Britta Saal elucidates:

While postcolonial critique undertakes an extension of Foucault, Gramsci, Derrida, and Lacan, while it realizes the problem of Orientalism (Said) and finally departs in its reflections from the postcolonial situation in India, decolonial critique has its roots in Latin America. It is based on approaches by critics of Eurocentrism like Jose Carlos Manategui, on dependency theory and on liberation philosophy. ${ }^{3}$

Ramón Grosfoguel distinguishes postcolonial studies from coloniality by asserting that the former conceptualizes the capitalist world-system as being constituted primarily by culture. For the latter, however, both culture and economy are equally important. ${ }^{4}$ Grosfoguel further distinguishes

1 Thinandavha Masha considers it an "epistemological and political movement"; see his "Unshackling the Chains of Coloniality: Reimagining Decoloniality, Africanisation and Reformation for a Non-racial South Africa, HTS Teologiese Studies/Theological Studies 74, no. 3 (2018): 4920, https://doi.org/10.4102/hts.v74i3.4920 (accessed November 10, 2020).

2 Walter Mignolo, "Epistemic Disobedience and the Decolonial Option," Transmodernity (Fall 2011): 44-65, here 45.

3 Britta Saal, "How to Leave Modernity Behind: The Relationship Between Colonialism and Enlightenment, and the Possibility of Altermodern Decoloniality," Budhi: A Journal of Ideas and Culture 17, no. 1 (2013): 49-80, here 60.

4 Ramón Grosfoguel, "La Descolonizacion de la Economia y los Estudios 
between coloniality and colonialism around the presence or absence of a colonial administration. Colonialism refers to situations "enforced by the presence of a colonial administration." Coloniality, on the other hand, continues "in the present period in which colonial administrations have almost been eradicated from the capitalist world-system." "' Thus, coloniality concerns both economic exploitation and the production of subjectivities and knowledge, and his antidote to the latter is the development of "border epistemologies." 6

Analogous to Grosfoguel's definition of colonialism by political control of people or land or resources by "foreign" administration is Eve Tuck and $\mathrm{K}$. Wayne Yang's argument that decolonization is not a metaphor. They reject "colonial equivocation" or "the vague equating of colonialisms that erase the sweeping scope of land as the basis of wealth, power, [and] law in settler nation-states." 7 They challenge Frantz Fanon and others who believe that "decolonizing the mind is the first step ... toward overthrowing colonial

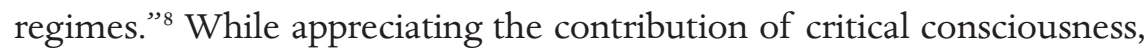
they believe frontloading critical consciousness-building can waylay decolonization. "Until stolen land is relinquished, critical consciousness does not translate into action that disrupts settler colonialism."

A terminological note as we continue: while decolonization and decoloniality are distinctive, their operations are often described as "decolonizing." For clarity I will distinguish between "decolonizing" and "decolonializing" to respect the differences in these concepts.

Postcoloniales: Transmodernidad, pensamiento fronterizo y colonialidad global," Tabula Rasa 48 (2006): 17-48; translated online as "Decolonizing Political Economy and Postcolonial Studies: Transmodernity, Border Thinking, and Global Coloniality," https://www.eurozine.com/transmodernity-border-thinking-andglobal-coloniality/ (accessed November 10, 2020).

5 Grosfoguel, "Decolonizing."

6 Ramón Grosfoguel, "The Implications of Subaltern Epistemologies for Global Capitalism: Transmodernity, Border Thinking and Global Coloniality," in Critical Globalization Studies, ed. Richard P. Appelbaum and William I. Robinson (New York and London: Routledge, 2005), 283-293.

7 Eve Tuck and K. Wayne Yang, "Decolonization Is Not a Metaphor," Decolonization: Indigeneity, Education \& Society 1, no. 1 (2012): 1-40, here 18.

8 Tuck and Yang, "Decolonization": 18.

9 Tuck and Yang, "Decolonization": 18. 


\section{Mind-Body}

The mind-body duality is an ancient concept in Western thought. René Descartes (d. 1650) is the pivotal voice of such dualistic thinking in modern Western philosophy with his je pense, donc je suis. ${ }^{10}$ This assertion created a new moment in Western thought that placed "Western man" as the foundation of knowledge; in the process "Descartes was able to claim non-situated, universal, omniscient divine knowledge" ${ }^{11}$ that the decolonial turn systematically analyzes and voraciously rejects. However, the consistent emphasis on epistemologies, indigenous knowledges, and minority discourse among contemporary decolonial thinkers could suggest that decoloniality is largely a cognitive enterprise.

Twentieth-century Western philosophers such as Henri Bergson (d. 1941) challenged Descartes' presumptions about knowing by moving the body toward the center of cognition. Bergson spoke about the "intelligence of the body," the "logic of the body," and "bodily memory." ${ }^{12}$ This corporeal turn ${ }^{13}$ has been embraced by many. Michel Foucault (d. 1984) consistently argued for the primacy of doing over knowing, of practice over belief. Jesse Prinz concludes that "a complete theory of consciousness will be an embodied theory, in a moderate sense of the term." ${ }^{14}$ Recently, neuroscientists have pushed even further, for example, in the emerging field of radical embodied cognitive science that studies the "embodied brain" and the necessity of new approaches for understanding the contribution of bodily capacities to cognitive processes..$^{15}$ Dancer, philosopher, and

10 First appearing in Part IV of his Discours de la Méthode Pour bien conduire sa raison, et chercher la vérité dans les sciences (Leyden:Ian Maire, 1637).

11 Grosfoguel, "Decolonizing."

12 Henri Bergson, Matter and Memory: Essay on the Relationship of Body to Spirit, trans. Nancy Margaret Paul and W. Scott Palmer (London: Allen Unwin, 1962), 137, 139, and 197 respectively.

13 This is language that Maxine Sheets-Johnstone foregrounds in her The Corporeal Turn: An Interdisciplinary Reader (Exeter, UK: Imprint Academic, 2009).

14 Jesse Prinz, "Is Consciousness Embodied?," The Cambridge Handbook of Situated Cognition, ed. Philip Robbins and Murat Aydede (Cambridge and New York: Cambridge University Press, 2009): 434.

15 E.g., see Julian Kiverstein and Mark Miller, "The Embodied Brain: Towards a Radical Embodied Cognitive Neuroscience," Frontiers in Human Neuroscience (May 6, 2015), doi.org/10.3389/fnhum.2015.00237. 
evolutionary biologist Maxime Sheets-Johnstone corrects "I think, therefore I am" with "I move, therefore I am." 16

\section{The Arts, Ritual Practice and DeCOlONiality}

While decolonial writings do emphasize the epistemic, there are rich strands in these writings underscoring the embodied nature of knowing, such as the emphasis on the marketplace. Mignolo identifies the market as one of the key loci where the rhetoric of modernity appears and the logic of coloniality is hidden. ${ }^{17}$ Grosfoguel has long held that geo-economic issues are inextricably intertwined with the geopolitical and geocultural processes of the modern/colonial world system. ${ }^{18}$ Aníbal Quijano pointedly examines how slavery itself was a market strategy for disposable manual labor, a strategy to commodify bodies for the enrichment of the colonizers. ${ }^{19}$

The decolonial turn can also be charted through the arts. ${ }^{20}$ Enrique Dussel recognizes that art is an ideology. Because of that, he argues that it is essential to study "the aesthetic production of works of art which express in their 'fidelity' to the face of the oppressed ... critical, prophetic and eschatological "beauty.", 21

16 Maxime Sheets-Johnstone, The Primacy of Movement, $2^{\text {nd }}$ ed. (Amsterdam: John Benjamins, 2011).

17 Mignolo, "Epistemic": 48.

18 Already in 1997, he was exploring the implications of economics on immigrants in his article, jointly published with Sherri Grasmuck, "Geopolitics, Economic Niches, and Gendered Social Capital among Recent Caribbean Immigrants in New York City," Sociological Perspectives 40, no. 2 (Summer 1997): 339-363.

19 Grosfoguel and Grasmuck, "Geopolitics": 536.

20 Nelson Maldonado-Torres, "Thinking through the Decolonial Turn: Postcontinental Interventions in Theory, Philosophy, and Critique-An Introduction," Transmodernity: Journal of Peripheral Cultural Production of the Luso-Hispanic World 1, no. 2 (2011): 2, https: / / escholarship.org/uc/item/59w8j02x (accessed November 10, 2020).

21 Enrique Dussel, "Christian Art of the Oppressed in Latin America (Towards an Aesthetics of Liberation)," in Symbol and Art in Worship, ed. Noel Maldonado and David Power, Concilium 132 (1980): 40-52, here 50. A significant work in theological aesthetics from a Hispanic perspective that emphasizes "lifting up the lowly" is Alejandro García-Rivera, The Community of the Beautiful: A Theological Aesthetics (Collegeville: Liturgical Press, 1999). 
A leading artistic form in this conversation has been literature and literary criticism. Besides literature, researchers also examine the role of music-making as a colonizing and colonializing technology. According to Robin James, one of the reasons why music is prominent in postcolonial studies is because the relationship between music and race or gender is an intersectional one. In James's view, a musical judgment is not simply about music, but is an "identity-constructing" formulation that works to "situate oneself in social relationship and identity categories." 22

Often intertwined with such musical studies are symbolic and ritual analyses. The emerging field of ritual studies has bolstered this approach, as it recognizes ritual as always some kind of exercise of power. ${ }^{23}$ The importance of ritual and the arts as gateways to both constructing and deconstructing human discourse is recognized by Sylvia Wynter:

It is ... precisely through fiction, ritual, and art that we can have access to the higher level units of our system-specific modes of mind and to the "enchanted" order of discourse which must everywhere function ... to conserve the grounding premises of its mode of inferential analogic from which its systemmaintaining "truths" are stably generated.... [T] he higher level of knowledge afforded by fiction, as indeed by religious ritual, myths of origin, etc., in effect provides access precisely to knowledge of those modes of rhetorical speech on whose basis all human orders are discursively erected. ${ }^{24}$

Ritual is a key form of meaning making, a long-employed technology for expressing and creating belief, yet also a tool of colonization and colonialization. Saal contends that one of the key forms of mental colonization in Africa was the superimposition of religion. ${ }^{25}$ Quijano is articulate about the repressive role of images, symbolization, and belief patterns in colonialism:

22 Robin James, "On Popular Music in Postcolonial Theory," Philosophia Africana 8, no. 2 (2005): 171-87, here 186.

23 Catherine Bell, Ritual Theory, Ritual Practice (New York and Oxford: Oxford University Press, 1992), esp. 197-223.

24 Sylvia Wynter, "On Disenchanting Discourse: 'Minority' Literary Criticism and Beyond," in The Nature and Context of Minority Discourse, ed. Abdul JanMohamed and David Lloyd (New York: Oxford University Press, 1990), 241.

25 Saal, "How to Leave Modernity Behind": 57. 
In the beginning colonialism was a product of a systematic repression ... of the specific beliefs, ideas, images, symbols or knowledge that were not useful to global colonial domination.... The repression fell, above all, over the modes of knowing, of producing ... images and systems of images, symbols, modes of signification, over the resources, patterns, and instruments of formalized and objectivized expression, intellectual or visual. It was followed by the imposition of the use of the rulers' own patterns of expression, and of their beliefs and images with reference to the supernatural. These beliefs and images served not only to impede the cultural production of the dominated, but also as a very efficient means of social and cultural control, when the immediate repression ceased to be constant and systematic. ${ }^{26}$

While Quijano never mentions Christianity here, the religion of the sixteenth-century colonizers was exclusively Christianity and originally Roman Catholic. Stephen Bevans summarizes: "The modern missionary era was in many ways the 'religious arm' of colonialism, whether Portuguese and Spanish colonialism in the sixteenth Century, or British, French, German, Belgian or American colonialism in the nineteenth." 27 While Christianity has supported many liberative movements in colonized areas, this does not mitigate the impact Christianity has had on persistent coloniality. Thus, in his definition of coloniality, Mashau believes that there is a coloniality of power, of knowledge, of being, but also a coloniality of faith. As a South African, he contends that " $[\mathrm{t}]$ he marriage between the empire and mission in the history of the church," for example, the Dutch Reformed Church in South Africa, validates such a proposal. ${ }^{28}$

If Christianity is so deeply implicated in colonizing and colonializing processes, its liturgies are by necessity also implicated. The worship of various faith traditions is increasingly examined from perspectives of colonization and coloniality. Marc Ellis unmasks liturgy as a technology of colonization and coloniality, noting that "liturgy often pretends that its domain is primarily or only religious" and recognizes that many "experience the proclamation of liturgy's innocence as naïve.” ${ }^{29}$ Kristine Suna-Koro

26 Aníbal Quijano, "Coloniality and Modernity/Rationality, Cultural Studies 21, nos. 2-3 (March/May 2007): 168-178, here 169.

27 Stephen Bevans, "New Evangelical Vision and Mission," Divine Word Missionary Magazine (2002): no pagination.

28 Mashau, "Unshackling."

29 Marc Ellis, "After the Holocaust and Israel: On Liturgy and the Postcolonial (Jewish) 
recognizes that "liturgy has been part and parcel of the coloniality of being, power and knowledges. Many Christian liturgies ... are still permeated with unexamined imperialistic symbols, images of conquest, patriarchy, and racism." " For Sarah Kathleen Johnson, Christian ritual is not only an instrument of social control but also an instrumental of cultural genocide. ${ }^{31}$

Consonant with Robin James's contentions about music, Becca Whitla has examined how hymn singing among Indigenous peoples in Canada was a way "to discipline and 'civilize' ... the children as an intentional means to eradicate their sacred indigenous practices and indigenous culture." 32 Anglican residential schools, replicating Anglican choir models of performance, were meant to "civilize, assimilate and Christianize students [and] to establish European sovereignty, beyond a shadow of a doubt." 33 "Hymn singing was part of a broader pattern of coloniality of music in which missionary hymnody itself subjugated, disciplined and controlled Indigenous bodies and children. ${ }^{34}$ Conversely, hymn singing can also be an act of epistemic disobedience and a decolonial mode for doing theology. ${ }^{35}$

Sarah Kathleen Johnson's more focused case study considers the impact of Christian ritual on Indigenous children who were sent to Canadian residential schools. Approximately 150,000 Indigenous children in Canada were sent to such schools meant to strip them of their language and culture, and ultimately to "Christianize and civilize." ${ }^{66}$ Evidence as far back as 1879 assembled by Canada's Truth and Reconciliation Commission (TRC,

Prophetic in the New Diaspora," in Liturgy in Postcolonial Perspectives, ed. Claudio Carvalhaes (New York: Palgrave MacMillan, 2015): 45-67, here 48.

30 Kristine Suna-Koro, "Puzzling over Postcolonial Liturgical Heteroglossia: In Search of Liturgical Decoloniality and Dialogic Orthodoxy,” in Carvalhaes, Liturgy, 241253, here 250 .

31 Sarah Kathleen Johnson, "On our Knees: Christian Ritual in Residential Schools and the Truth and Reconciliation Commission of Canada," Studies in Religion/Sciences Religieuses 41, no. 1 (2018): 3-24, here 6.

32 Becca Whitla, "The Colonizing Power of Song," in Decoloniality and Justice: Theological Perspectives, ed. Jean-François Roussel (São Leopoldo, Brazil: Oikos, 2018), 43-50, here 45.

33 Whitla, "Colonizing," 47.

34 Whitla, "Colonizing," 46.

35 Becca Whitla, "Singing as Un Saber del Sur, or Another Way of Knowing," Toronto Journal of Theology 33, no. 2 (2017): 289-294.

36 Johnson, "Knees," 4. 
2008-2015) documents that "a central element of the education provided at these schools would be the destruction of Aboriginal Spirituality." ${ }^{37}$ The TRC report describes Canada's approach to Indigenous people as "cultural genocide," with specific spiritual aspects: "Spiritual leaders are persecuted, spiritual practices are forbidden, and objects of spiritual value are confiscated and destroyed." 38 Johnson's analysis is grounded in the work of Foucault - and from Mignolo's view of genealogy discourse appears more as postcolonial rather than decolonial analysis. On the other hand, her work takes a decolonial turn as she underscores the destructive role of Christian ritual vis-à-vis indigenous patterns of believing, practicing, and knowing.

\section{Misa ng Bayang Pilipino: A Roman Catholic Case $\mathbf{S}$ Tudy}

Misa ng Bayang Pilipino (MBP) is one of the more theologically informed and radical adaptations of the Roman Catholic Mass since Vatican II (1962-65). MBP was composed in 1975. Leading this effort was Filipino scholar Anscar Chupungco (d. 2013) in collaboration with the Maryhill School of Theology in Quezon City. A preeminent voice on inculturation, Chupungco taught on the faculty of the Pontifical Institute of Sacred Liturgy in Rome (1973-97), eventually becoming president (1978-86), then Rector Magnificus of the Pontifical Athenaeum of St. Anselm (1986-90). He also served as consultor to the Vatican's Congregation for Divine Worship (1978-1993). While approved by the Catholic Bishops' Conference of the Philippines in 1976 and publicly celebrated by members of the Filipino hierarchy-including the current Archbishop of Manila, Cardinal Luis Antonio Tagle $-M B P$ was never officially approved by the Vatican.

Because Chupungco was classically trained in liturgy, $M B P$ predictably follows closely the structure of the Roman Catholic Mass. However, there are notable variations:

37 From Honouring the Truth, Reconciling for the Future: Summary of the Final Report of the Truth and Reconciliation Commission of Canada, online at http://publications.gc.ca/ site/eng/9.800288/publication.html, as cited in Johnson, "Knees": 6.

TRC Summary, 1, as cited in Johnson, "Knees": 7. 
1) The priest-presider carries the cross in the opening procession, and following the opening doxology blesses the people with it. ${ }^{39}$

2) The sign of peace occurs after the Gloria before the opening prayer. ${ }^{40}$

3) At beginning of the Liturgy of the Word the priest-presider ${ }^{41}$

a. introduces the Liturgy of the Word

b. holds the Book of the Gospels high while the people sing a doxology

c. receives the traditional gesture of respect (mano po) from the readers, and then blesses them.

4) During both versions of the eucharist prayer:

a. The traditional three-part opening dialogue is changed: ${ }^{42}$

i. The priest-presider offers the traditional greeting, Sumainyo ang panginoon ("The Lord be with you") with the people's response.

ii. The second and third traditional exchanges before the Preface are replaced by an introduction by the priest-presider and a more extended sung response by the people (Purihin at ipagdangal), during which candles are lit and the bells rung.

b. The priest-presider and people make the sign of the cross. ${ }^{43}$

c. The people sing a further eight or nine acclamations or responses throughout Eucharistic Prayers I and II:

i. three or two before as part of the Pagbubunyi ("Exaltation/ preface") before the institution narrative ${ }^{44}$ that partially translates and partially replaces the traditional Sanctus

ii. one at the traditional place of the "Mystery of faith" acclamation after the institution narrative ${ }^{45}$

iii. four litanic responses during the closing intercessions for the living and the dead ${ }^{46}$

iv. and the great Amen. ${ }^{47}$

39 Since there are some differences from the various printings of this ritual, this analysis is based on the "official" version published in The Supplement to the Roman Missal for the Dioceses of the Philippines (1999), 133.

40 Supplement, 140.

41 Supplement, 141-142.

42 Supplement, 150-151, 163-164.

43 Supplement, 152 and 164.

44 Supplement, 152-155 and 165-166.

45 Supplement, 159 and 169.

46 Supplement, 161-162 and 171-172.

47 Supplement, 162 and 173. 
d. The priest-presider does not include the elevation or gesture of reverence after the institution narrative over the bread, ${ }^{48}$ which is moved after the text over the cup, when both elements are raised together. ${ }^{49}$

5) During the Communion Rite ministers of communion receive after distribution of communion to the faithful; the priest-presider receives last. $^{50}$

6) During the dismissal rite:

a. The usual invitation/response ("The Lord be with you...") is eliminated.

b. The priest-presider recalls the theme of the celebration. ${ }^{51}$

c. The priest-presider blesses the people with the cross. ${ }^{52}$

d. The priest-presider raises the cross while the people sing an acclamation. ${ }^{53}$

Aside from structural variations, Jesus Malit believes the most significant feature of this adaptation is that it "translates the meaning of the Eucharistic celebration into the Filipino linguaggio and nature forms of expression." ${ }^{54}$ To exemplify, Malit provides an extensive analysis of Eucharistic Prayer I in $M B P$.

In notes accompanying the originally published rite, Chupungco comments that Eucharistic Prayer I "expresses values that Filipinos traditionally cherish: reciprocity (pagtitiwala, utang na loob, pagpupuno ng kakulangan) and solidarity (pakikisama, pakikiramay)." ${ }^{55}$ These elements are apparent in the Paanyaya ("invitation") at the outset of the Eucharistic

48 Supplement, 157 and 168.

49 Supplement, 158 and 169.

50 Supplement, 176.

51 Supplement, 177.

52 Supplement, 177.

53 Supplement, 178.

54 My former student, Rev. Dr. Jesus Malit, wrote his professional doctoral thesisproject under my direction, which serves as a key resource for this analysis: Jesus Malit, "From Berakah to Misa ng Bayang Pilipino" (EDMin Thesis-project, Catholic Theological Union, 2001), 99.

55 Anscar Chupungco, Misa ng Bayang Pilipino: A Study on Liturgical Indigenization (Manila: Benedictine Abbey, 1975), 18. 
Prayer, which follows the standard opening: Sumainyo ang Panginoon ("The Lord be with you"). This Paanyaya incorporates and displaces the ordinary second and third responses of this opening invitation ("Lift up your hearts" and "Let us give thanks to the Lord our God").

$\begin{array}{ll}\text { Mga kapatid } & \text { Brothers and sisters, } \\ \text { Halina 't ating ipaubaya } & \text { Let us entrust } \\ \text { Ang lahat ng alalahanin sa } & \text { our cares to God } \\ \text { Diyos: } & \text { and render all praise } \\ \text { Tanang papuri at pasasalamat } & \text { thanksgiving } \\ \text { Sa kanya ay ating ihandog. } & \text { to him. }{ }^{56}\end{array}$

\section{Malit notes:}

The Pilipino paanyaya sets the tone for the introductory dialogue. Paanyaya is a solemn and formal act of inviting someone to a celebration and a meal. Because it is formal (and probably to avoid the embarrassment of being turned down), it is usually extended through a third party. Thus the dialogue is in fact a solemn invitation to the eucharistia and is here embellished in a beautiful Filipino cultural expression....

The Pilipino ${ }^{57}$ language reveals its inclusive nature in the opening dialogue's address to brothers and sisters. There is only one word in Pilipino to encompass these terms: kapatid. It follows naturally that Pilipino pronouns are all-inclusive in character, too. ${ }^{58}$

The Pagbubunyi ("Exaltation") that follows is a reimagination of the preface according to a Filipino traditional act of homage. This solemn act is a speech that exalts the achievements of the person being honored. The people applaud or shout Mabuhay ("Long Live") to affirm the praise articulated by the leader. ${ }^{59} \mathrm{MBP}$ 's adaption of this form employs a typical Filipino social pattern expressing modesty before a higher-ranking person: ${ }^{60}$

\footnotetext{
56 Malit, "Berakah," 103.

57 This is a common way "Filipinos" reference themselves.

58 Malit, "Berakah," 102-3.

59 Malit, "Berakah," 104.

60 Malit, "Berakah," 105.
} 


\author{
Ama namin \\ ikaw ang tanging kapuri-puri \\ at siyang dapat pasalamatan. \\ Kapos ang aming dilang magpahayag \\ ng iyong kapangyarihan \\ at walang hanggang awa. \\ Kaya nga ikaw na lumikha sa tanan \\ Ay amin ngayong ipinagbubunyi
}

\author{
Our Father \\ you are the only one who is \\ praiseworthy \\ And is to be thanked. \\ Our tongues fail us when we \\ speak \\ of your power \\ and everlasting mercy. \\ That is why we exalt you \\ because you have created \\ everything $^{61}$
}

Malit draws our attention to the use of the idiomatic expression kapos ang dila, literally "the tongue is too short," symbolizing Filipino modesty and deference. Next Malit contrasts this "exaltation" with other creationcentered prefaces, commenting:

True to the Filipino social pattern, the text does not stress the importance of created things themselves, but the personal relationship between the Creator and the creature. Thus the prayer does not dwell on the sun, the moon and the stars, nor on rivers, mountains and flowers in the fields, but on humanity's attitude towards God. ${ }^{62}$

The final section of this opening exultation gives special attention to Mary:

Amang mahabagin
sa takdang panahon
nilubos mo ang iyong pangako
isinugo mo ang iyong Anak na si Hesukristo.
Kinalungdan mo ang Berheng Maria
at kukod mo siyang pinagpala sa babaeng lahat
upang sa kapangyarihan
ng Espiritu Santo
siya ay maging Ina
ng iyong bugtong na Anak.

Amang mahabagin sa takdang panahon nilubos mo ang iyong pangako isinugo mo ang iyong Anak na si Hesukristo. Kinalungdan mo ang Berheng Maria at kukod mo siyang pinagpala sa babaeng lahat upang sa kapangyarihan siya ay maging Ina ng iyong bugtong na Anak.
Compassionate Father at the appointed time You fulfilled your promise: You sent your son, Jesus Christ. You favored the Virgin Mary and blessed her among all women That through the power of the Holy Spirit She will be the Mother of Your only begotten Son. ${ }^{63}$

61 Malit, "Berakah," 105 (modified by author).

62 Malit, "Berakah,"105 (modified by author).

63 Malit, "Berakah," 109 (modified by author). 
Given the deep devotion of many Filipinos to Mary, "to a certain measure this liturgical prayer provides a rightful place to popular, indeed filial piety of Filipinos to the Mother of God." ${ }^{64}$ This is quite unusual, as gestures to popular religiosity seldom appears at the heart of Roman Catholic eucharistic praying.

The central core of the Eucharistic Prayer-consecratory epiclesis, institution narrative, anamnesis, offering, and communion epiclesisfollows more closely the formulae found in the Roman Missal. Notable nuances occur in the consecratory epiclesis, which prays for the Spirit to be given to the church (ipagkaloob mo sa iyong Simbahan ang Espiritu ng kabanalan, "Grant to your Church the Spirit of Holiness") and not simply to come upon the elements of bread and wine as in the official Latin text. This inculturated epiclesis also seems to mirror the prefaces' emphasis on relationality. The use of ipagkaloob ("grant") is significant as it "contains the sense of giving a gift (kaloob) ... that comes from one's heart (loob)." 65 As there is no equivalent word in Filipino for "epiclesis," the text uses lukaban, which "literally means 'to hatch' [or take under the wing], an action which is transferred here to the action of the Holy Spirit on the gifts." ${ }^{66}$ Similar language is employed in the communion epiclesis, during which "the priest stretches out his arms towards the people." ${ }^{.67}$ Ipagkaloob is again invoked, implying that the Holy Spirit is a "heart" gift. Lukuban also again appears here, which Malit translates as the Spirit taking us "lovingly under his wings." ${ }^{68}$

Regarding the institution narrative, Malit concludes, "through the careful choice of culturally significant words, the elements of history, memorial meal, sacrifice, fellowship and celebration have been highlighted in the institution narrative." ${ }^{69}$

A final telling text is the third petition before the intercession of saints:

\footnotetext{
64 Malit, "Berakah,” 109.

65 Malit, "Berakah," 111.

66 Malit, "Berakah," 111.

67 Supplement, 199, 160, and 171.

68 Malit, "Berakah," 114.

69 Malit, "Berakah," 113
} 


\author{
Imulat mo kami \\ sa aming pananagutan sa isa't isa lalo \\ na sa mga sawimpalad, \\ api at dukkha upang kaming lahat \\ ay mamuhay nang may pagsusumikap \\ at sariling paninindigan \\ ayon sa iyong banal na kalooban. \\ Iniluluhog namin.
}

\author{
Open our eyes \\ to our responsibility to one \\ another \\ especially those who suffer, \\ the oppressed and poor \\ so that all of us may live our lives \\ with diligence \\ and conviction \\ according to your holy will. \\ We beg of you.
}

Notably, this text was crafted while Ferdinand Marcos (d. 1989) was president of the Philippines (1965-86) and during the period of martial law (1972-81).

The verb imulat means "to open the eyes" and so God is invoked to open our eyes to our pananagutan ["social responsibility"]. In the climate of liberation and social justice that are concrete and relevant issues in the Philippines, such words as pananagutan ["social responsibility"], pagsusumikap ["diligence" or "preserving effort to achieve one's goal"], paninindigan ["conviction"] have special relevance. These words, often used in slogans, infused a social justice dimension to the Eucharistic celebration. The text does not forget to remind us that our efforts must be in accord with the banal na kalooban ["holy will"] of God. For a Filipino divine kalooban expresses not merely the firmness of God's will, but also God's love and providential disposition of all things. ${ }^{70}$

\section{Analysis: Decolonization or DeCOlONIALIZATION?}

From a postcolonial perspective, there is much evidence of borrowing and subverting traditional Roman Catholic prayers and rubrics in MBP: the colluding that opens a "third space" between the colonizer and colonized. ${ }^{71}$ Structurally the Eucharistic Prayer is substantially that found in the Latin, there is yet consistent structural pushback demonstrating that this ritual is reclaiming aspects of language and culture and critiquing

70 Malit, "Berakah," 115.

71 Homi Bhabha, "The Commitment to Theory," in New Formations 5 (1988): 5-23, as cited in The Post-Colonial Studies Reader, ed. Bill Ashcroft, Gareth Griffiths, and Helen Tiffin (London: Routledge, 1995): n. 32, 209. 
contemporary Roman euchology. For example, the unusually high incidence of congregational responses validates the cultural values of solidarity and reciprocity that Chupungco predicated of this text ${ }^{72}$ and implicitly critique the traditional and enduring dominance of the priestpresider. The consolidation of gestures of honor to the consecrated bread and cup into a single act seems to critique the Roman tradition focused on a single moment of consecration instead of respecting the whole prayer as consecratory.

Various adaptations could rightfully be considered cultural hospitality markers, such as moving the sign of peace to the entrance rites. The instruction for communion ministers to receive after everyone else, with the priest-presider as the final communicant, embodies a graciousness hospitality for the eucharistic guests who are fed before the "host."

$M B P$ also makes important gestures to the popular religiosity of Filipinos by giving Mary significant mention in the preface. Given the importance of the cross in the Filipino imagination, the priest-presider rather than an acolyte carrying in the cross and the final blessing with the cross gestures clearly toward a Filipino imagination. Finally, the strong social justice strand takes seriously the contexts at the time of MBP's writing.

$M B P$ does not radically rearrange Roman euchological patterns, nor displace the hierarchical structures of the Roman Catholic Church. Decolonizing elements here could be considered very modest. Their Roman Catholic context, however, renders them more prominent. The fact that $M B P$ continues to be celebrated by prelates without official Roman approval is itself decolonizing data.

The issue of language puts us on the border between decolonization and decolonialization. Tuckman and Yang were clear that decolonization is all about returning the land. In MBP Filipinos have taken back not their land but their language. On the one hand, this could be considered an act of decolonization. Yet, so many scholars have argued that decoloniality is about indigenous knowledges and minority discourse. MBP is imbued with indigenous knowledges in maxims, proverbs, and metaphors that instinctively ring true to the native Tagalog speaker. This is border discourse and a striking reimagination of Roman Catholic prayer from a subaltern

72 See note 55 above. 
perspective. It is not only a decolonized expression of worship but also clearly moves in the direction of decolonialized worship.

Kristine Suna-Koro raises some difficult questions. Evoking Frantz Fanon's powerful image of les damnés de la terre, Suna-Koro asks, "can the truth of subaltern suffering, as well as longing for respectful recognition ... be heard in liturgical praise? Can those whose lives, languages, wisdom traditions and cultural memories have been conquered and colonized speak and be seen for what they really are in postcolonial worship? Can the damnés de la terre truly sing, dance, and praise in our liturgies ?" ${ }^{\prime 3} \mathrm{MBP}$ seems to suggest that such is possible.

\section{About author}

Edward FOLEY, Capuchin (Ph.D., University of Notre Dame) is Duns Scotus Professor Emeritus of Spirituality and retired Professor of Liturgy and Music at Catholic Theological Union, Chicago, Illinois.

73 Suna-Koro, "Puzzling," 251. 